
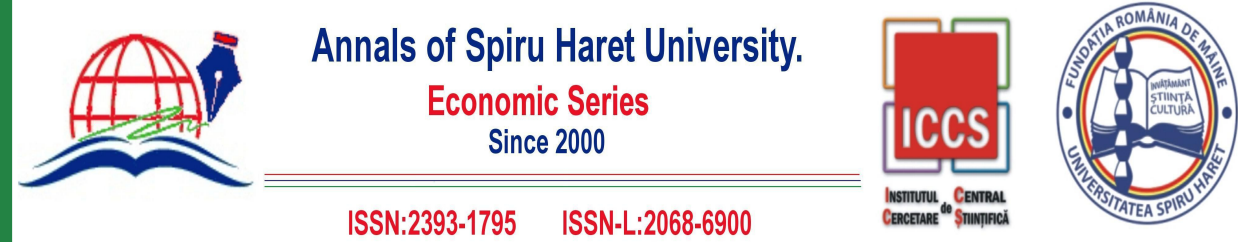

Issue 4/2019

\title{
DOES TAXATION HAS IMPACT ON INVESTMENT? AN EMPIRICAL RESPONSE FROM CO-INTEGRATION ANALYSIS
}

\author{
Tajudeen Adejare ADEGBITE ${ }^{1}$ \\ ${ }^{1}$ Ph.D., ACA., Senior Lecturer, Department of Accounting, Al-Hikmah \\ University, Ilorin, Kwara State, Tel.: +2348035793148, \\ Email: adetajud@yahoo.com
}

How to cite: ADEGBITE, T.A. (2019). "Does Taxation Has Impact on Investment? An Empirical Response from Co-Integration Analysis." Annals of Spiru Haret University. Economic Series, 19(4), 57-74, doi: https://doi.org/10.26458/1944

\section{Abstract}

This study examined the effect of taxation on investment in Nigeria from 1970 to 2018. Relevant secondary data were obtained from Central Bank of Nigeria (CBN) Statistical Bulletins and Federal Inland Revenue Services Bulletin from 1970 to 2018. Regression analysis technique, Units root test, Johansen cointegration, Vector Error-Correction Model, and Granger causality tests were employed to determine the long run relationship and causality links among the variables. Results showed that PPT and Value added tax had positive significant impact on INV both in the short run and in the long run while Company income tax, and Custom and Excise duties impacted INV negatively. It is concluded that all components of taxes had positive significant impact on investment in Nigeria except corporate income tax. Corporate income tax had negative significant impact on investment both in the short run and in the long run.

Keywords: taxation; investment; co-integration analysis; corporate income $\operatorname{tax}$.

JEL Classification: $\mathrm{H} 20$ 


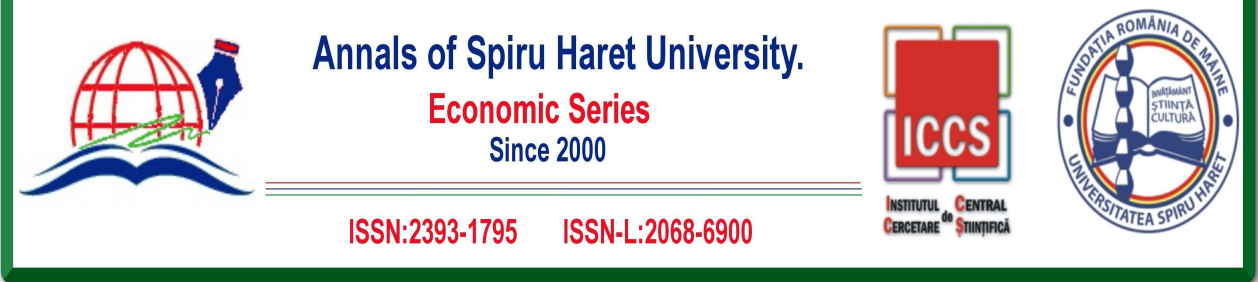

\section{Issue 4/2019}

\section{Introduction}

Taxation is an instrument of fiscal policy adopted by government in transforming various aspects of economic growth and investment in the country. It is also referred to as a way by which government forcefully shares a fractional part of income of individual and private organization with the disposition of fulfilling fiscal responsibilities. Investment decisions of individual and organization depend on the available funds which are initiated through savings and access to funds. It does not depend on effective average tax rates, but does depend on effective marginal tax rate when the firms are financially constrained. Low income tax people have more disposable income that can be used for saving and investment. Buttner, Overesch, Schreiber and Wamser (2006) opined that active tax rates are important for both policy makers and business managers to access the investment tax burden. Heavy taxes can reduce the intention to invest, especially if the tax is heavily on savings and profits. All the discrimination features of the companies income tax stems from the fact that company's net income is the base. The tax falls more heavily on activities with low rations of debt and it is a deductible expense. However, the Nigerian companies' income tax attempts to attract investment in certain preferred sectors by giving tax incentive to firms engaged in such activities. Contrary to this, tax policy affects economic growth by discouraging new investment and entrepreneurial incentives or by distorting investment decisions [Chigb et al., 2012]. The economic benefits of any investment to organization and individual are diminishing by tax rate. Tax policy distorts the investment from high tax sector to the low tax sector with low efficiency by affecting the marginal productivity of the capital [Harberger, 1962]. Arising from this perspective, this study examined the effect of taxation on investment in Nigeria from 1970 to 2018. Based on the objective of the study, the following hypotheses stated were tested:

$\mathrm{Ho}_{1}$ : Taxation has no significant effect on investment in Nigeria.

$\mathrm{Ho}_{2}$ : Taxation has no long run relationship with investment in Nigeria.

$\mathrm{Ho}_{3}$ : There is no causality between taxation and investment in Nigeria.

\section{Literature Review and Theoretical Framework}

\section{Tax Reform and Investment}

Taxation is referred to as a system in which income of individuals and private organizations are levied by government in which a fractional part of the income is paid into the government purse so that the political promises of the government will 58 


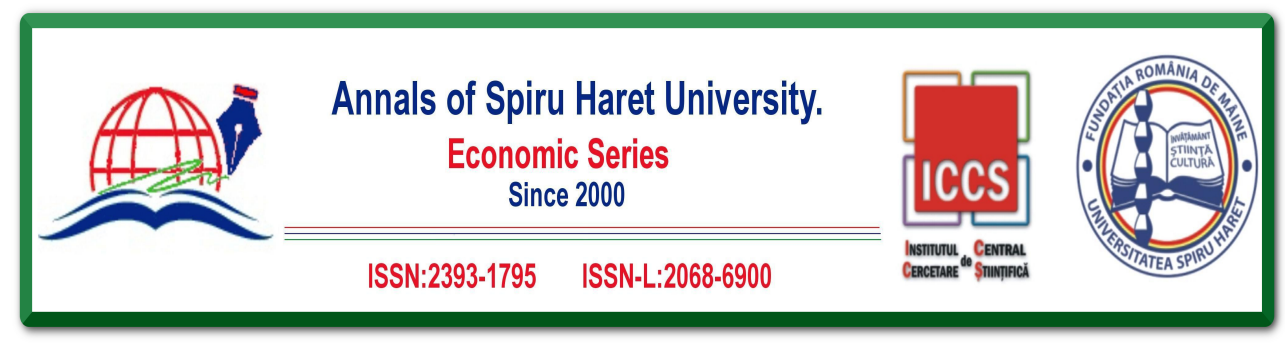

Issue 4/2019

be fulfilled in terms of fiscal responsibilities. Taxation can strongly impact on investment by first impacting on the investment climate. A country's tax system has a strong effect on other macroeconomic indicators, hence has a systematic, predictable and regular relationship with economic growth and development. Measures to spur investment through tax reduction command wide-spread support. Investment incentives of taxation can be roughly divided into three categories - reduction in the effective price of new capital goods through the investment tax credit or accelerated depreciation, reduction in the corporate tax rate and reductions on the returns on investment at the personal level [Chigbu et al., 2012].

Multiple taxation increases the cost of production, reduces the international competitiveness of locally produced goods and hinders inter-state commerce [Chartered Institute of Taxation of Nigeria, 2002], high corporate income tax reduces the cash flow of business enterprises, hence stiffens their investment capacity. To this extent, tax reforms that reduce the tax rate and eschew multiplicity of taxation will not only improve the investment climate, but leverage investment capacity by beefing internal fund for business enterprises. Thus, tax reforms are designed to serve three functions. They are: amendatory function, the innovative function and the revenue function. While the amendatory role attempts to correct weakness in the tax system, the innovative function attempts to introduce something new in the tax regime and the revenue role attempts to beef up public tax generated revenue by broadening the tax base and preventing tax evasion and avoidance [Nwokoye \& Rolle, 2015].

According to Tosun and Abizadeh (2005), there are five possible mechanisms by which taxes can affect economic growth. First, taxes can inhibit investment rate through such taxes as corporate and personal income, capital gains taxes. Second, taxes can slow down growth in labour supply by distorting labour-leisure choice in favour of leisure. Third, tax policy can affect productivity growth through its discouraging effect on research and development expenditures. Fourth, in a Harbenger framework, taxes can lead to a flow of resources to other sectors that may have lower productivity. Finally, high taxes on labour supply can distort the efficient use of human capital high tax burdens.

\section{Underpinning Theory}

Theories of Investment

Panoply of both theoretical and empirical studies mainly focused on the determinants of fixed business investment. There is a general consensus that business 

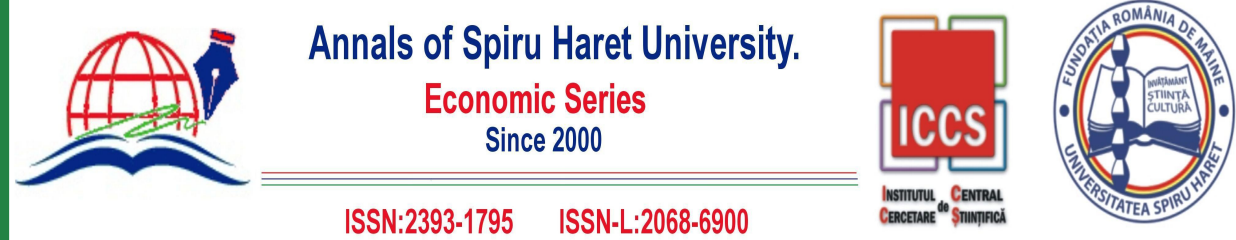

\section{Issue 4/2019}

environment significantly impact on investment decisions. The tax regime of any country has been established as one of the determinants of its business climate. A key area of controversy is whether depreciation allowance and tax credit influences investment in physical assets. Several investment models have been formulated to examine the determinants of investment decisions. Three of these models will be examined. They are the accelerator model, the neoclassical model and the cash flow model. The accelerator model assumes fixed capital-output ratio, proposing that the relationship between capital and output is technologically fixed. The model expresses change in capital stock as a multiplier function of change in output. Thus, the determinant of investment is change in output [Jhingan, 1976; Iyoha, 2003]. Adopting this model implies that tax benefits such as depreciation allowance and tax credits cannot influence investment decisions, since investment is solely determined by output. If the tax rate is increased, the purchase power of the individual and organization reduces, which will invariably reduce the level of saving and this will affect the level of investment.

Review of Empirical Studies on the Relationship between Taxation and Investment in Nigeria

Muhammed and Jumbo (2012) empirically examined the impact of Pakistan taxes on investment and economic growth. The study utilizes the Ordinary Least Square method for estimating the growth model, while the Johansen's co-integration test was utilized in estimating the investment model. Results reveal that taxes do not directly impact on economic growth, but it does indirectly influence investment. Thus, higher income taxes impeded growth and result in dis-investment due to the savings channel. Newman (1998) examines the impact of tax reform on revenue productivity in Ghana. The study concluded that tax reforms impacts on productivity positively and significantly. However, this study was carried out in Pakistan not in Nigeria, therefore the results cannot be generalized and extended to Nigeria.

Adegbite and Usman (2017) study examined the effect of taxation on investment in Nigeria. It also looked at the direction of causality among Petroleum profit tax (PPT), Value added tax (VAT), Company income tax (CIT), Custom and excise duties (EXCISE), and Investment (INV) employing the method of Johansen cointegration and the Granger causality tests using data spanning the period 1981-2013. Results showed that petroleum profit tax has positive significant impact on investment both in the short run and in the long run with $(\beta=0.1472065 ; t=2.89$; 


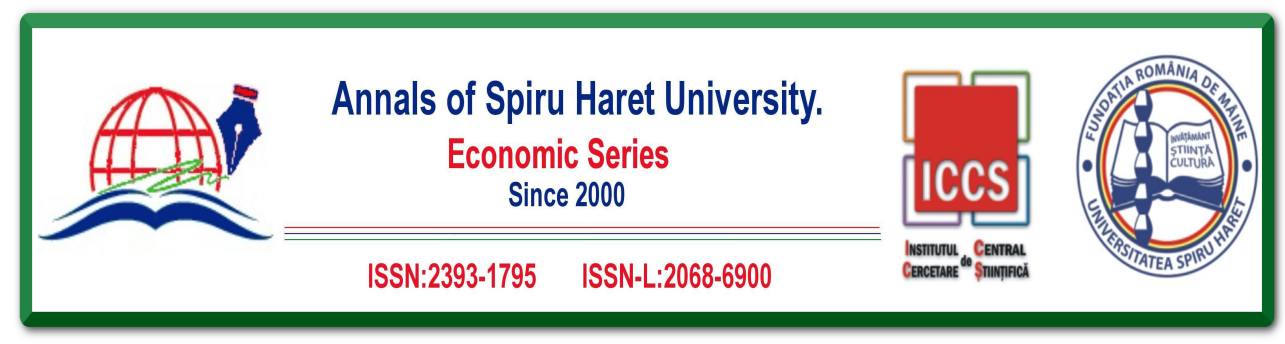

Issue 4/2019

$\mathrm{P}>|\mathrm{t}|=0.000)$ and $(\beta=0.1269068 ; \mathrm{z}=-5.99, \mathrm{P}>|\mathrm{z}|=0.000)$ respectively. Also, PPT granger-cause INV. Value added tax and Company income tax have positive impact on INV in the short run $(\beta=0.2060944 ; 0.0675709 \mathrm{t}=3.71 ; 2.59, \mathrm{P}>|\mathrm{t}|=0.000$ respectively) but negative impact in the long run $(\beta=-.1130489 ;-0.0915747 \mathrm{t}=$ $-4.62 ;-11.93, \mathrm{P}>|\mathrm{t}|=0.000$ respectively). Custom and Excise duties impacted INV negatively both in the short run and in the long run. $(\beta=-0.1930202 ; \mathrm{t}=-1.20, \mathrm{P}>|\mathrm{t}|$ $=0.000)$ and $(\beta=-.5798377 ; \mathrm{z}=-8.70 ; \mathrm{P}>|\mathrm{z}|=0.000)$ respectively. It is recommended that, once company income tax impacted investment negatively in the long run, Government should reduce the rate of company income tax in order to enhance the level of investment both local and foreign direct investment which will invariably reduce poverty and unemployment rate in Nigeria. However, this study was limited to 2013, many policies have been formulated after this scope, and therefore the results cannot be generalized.

Edame and Okoi (2014) examined the impact of taxation on investment and economic growth in Nigeria from 1980 to 2010. The ordinary least square method of multiple regression analysis was used to analyze the data. The annual data were sourced from the Central Bank of Nigeria statistical bulletin and NBS. The result of the analysis showed in conformity to our prior expectation because the parameter estimates of corporate income tax (CIT) and personal income tax (PIT) appears with negative signs, this means that an inverse relationship exists between taxation and investment. The economic implication of the result is that a one percent $(1 \%)$ increase in CIT will result in decrease in the level of investment in Nigeria. Consequently, an increase in PIT will result in decrease in the level of investment. Finally, the result therefore showed that taxation is negatively related to the level of investment and the output of goods and services (GDP) and is positively related to government expenditure in Nigeria. It was observed that taxation statistically is significant factor influencing investment, GDP and government expenditure in Nigeria. Based on the result, the study recommended that the government of Nigeria should use taxation to achieve its set target that will enhance economic growth and development. However, this study was restricted to 2010, but not prolonged to 2018 .

Mihai and Dan (2011) examined the impact of tax on economic growth for the Romanian economy. Using the method of Vector Auto regression (VAR), and examining the statistical properties of the variables based on Kwaitokowski-Phillip Schemidt Shin and Phillip-Peron tests, the researchers admonish that tax policy in Romania cannot be taken to extremes, and thus suggested that caution be taken in the implementation because a large amount of factors that could not be accounted for 


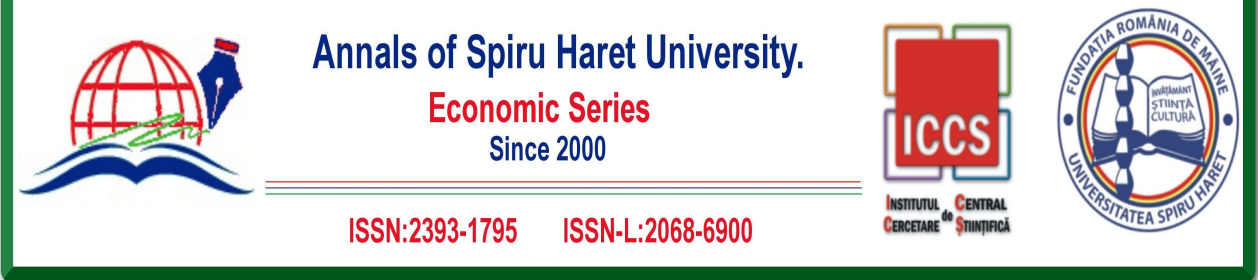

\section{Issue 4/2019}

may have influenced the results. Nevertheless, this study was only covered and restricted to taxation on economic growth in the Romanian economy not in Nigeria.

Nwokoye and Rolle (2015) examined the investment implication of the series of tax reforms in Nigeria, particularly the tax reforms of 2003 and National tax policy of 2012. Annual time series data spanning the years 1981-2012 were utilized. Preliminary diagnostic test was conducted to examine whether the estimated model satisfies the OLS assumptions. The basic assumptions of the OLS were satisfied. The result of the estimated OLS model shows that tax reform as proxied by VAT and CIT, both positively and significantly stimulate investment in Nigeria. The study recommends that efforts should be made towards intensifying the tax reforms. Further, policies should be directed towards redressing multiple taxation and high company income tax as both have the tendency to adversely affect investment. However, the study employed OLS model to examine the effect of tax reforms on investment, other econometric tests were ignored, and the years of study did not extended to 2018 .

Rodrigo (2004) empirically examined the relationship between tax reforms and private investment using Chile data. He employed data for the years ranging 19752005. The study confirmed the findings and found that tax reforms stimulate investment by freeing up investible resources. Similarly, the results were limited to Chile not Nigeria. In addition, the scope was confined to 2005 not strengthen to 2018

Mika, Andrew and Shiv (2012) examined the impact of the tax system on small and medium scale enterprises (SMEs) in Shinyanga Municipality, Tanzania. The study utilized the primary data approach, which was analyzed using descriptive statistics using frequencies and percentages. The results showed that majority of the respondents' position that the prevailing tax system is detrimental to the robust performance of small and medium scale enterprises (SMEs). Thus, the study suggested the reforming of the tax policies. However, this study only examined the effect of tax system on the performance of small and medium scale enterprises (SMEs) in Tanzania but Nigeria was not covered in the scope of the study.

From the review of previous works, the gaps identified are scope, methodology and conceptual gap. This is because the majority of the studies seen and reviewed are conducted in Nigeria with different scope, methodology and concepts, and the findings may not be generalized in wider perspectives. Thus, this study is exclusive and is expected to contribute to knowledge by employing unique econometric tests to investigate the impact of taxation on investment in Nigeria. 

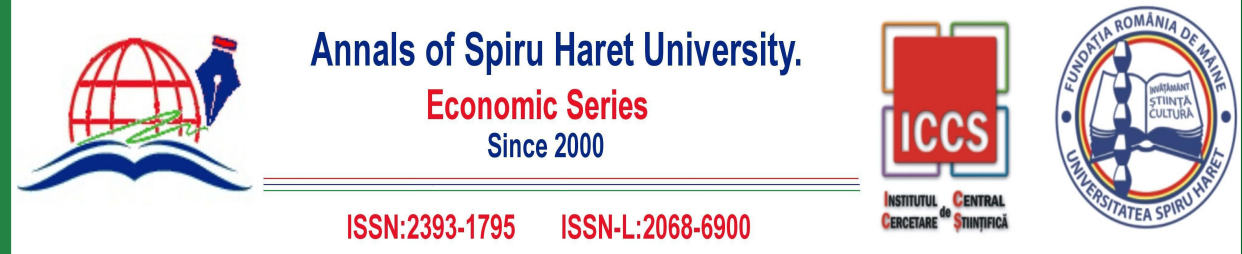

Issue 4/2019

\section{Methodology}

Secondary data were used in this study. The relevant data for the study were obtained from Central Bank of Nigeria (CBN) Statistical Bulletins and Federal Inland Revenue Services Bulletin from 1970 to 2018. Regression analysis technique was used to measure the effects of independent variables on dependent variable while Units root test, Johansen co-integration, Vector Error-Correction Model, and Granger causality tests were employed to determine the long run relationship and causality links among the variables.

\section{Model Specification}

Investment (proxied private investment) is the dependent variable that is the explained variable while the explanatory variables are company income tax, petroleum profit tax, value added tax, and Custom and Excise duties. This can be specifically stated as:

INV $=f\left(\right.$ CORPT $\left., P P T, V A T, C U S E X C_{,} \mu\right)$

Note that the proxy for economic growth is GDP; hence it will be used for the study. The multiple regression equation based on the above functional relation is:

$\sum_{i=1}^{n} I N V=a 0+\sum_{i=1}^{n} a 1 P P T+\sum_{i=1}^{n} a 2 V A T+\sum_{i=1}^{n} a 3 C O R P T+\sum_{i=1}^{n} a 4 C U S E X C+\mu 1$

Transforming equation (6) to the natural logarithm it changed to:

$\sum_{i=1}^{n}$ LOGINV $=00+\sum_{i=1}^{n} a 1 L O G P P T+\sum_{i=1}^{n} a 2 L O G V A T+\sum_{i=1}^{n} a 3 L O G C O R P T+\sum_{i=1}^{n} a 4$ LOGCUSEXC $+\mu 3$

\section{Results and Discussion}

The unit root test and multiple regression analysis, Johansen Tests for Cointegration, Vector Error-Correction Model, and Granger Causality Wald Tests results are presented below. 


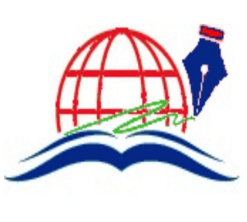

Annals of Spiru Haret University.

Economic Series

Since 2000

ISSN:2393-1795 ISSN-L:2068-6900
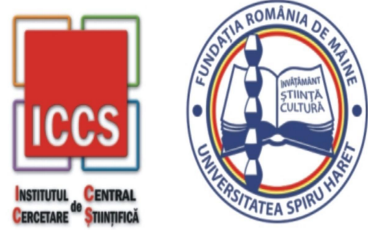

Issue 4/2019

Table 1. Unit Root Test

\begin{tabular}{lllllll}
\hline Variables & ADF stat & $\begin{array}{c}1 \% \\
\text { critical } \\
\text { value }\end{array}$ & $\begin{array}{c}5 \% \text { critical } \\
\text { value }\end{array}$ & $\begin{array}{c}10 \% \text { critical } \\
\text { value }\end{array}$ & $\begin{array}{c}\text { Order of } \\
\text { integration }\end{array}$ & Remark \\
INV & 3.822 & -3.628 & -2.950 & -2.608 & $\mathrm{I}(0)$ & Stationary \\
PPT & $3.764 * * *$ & -3.655 & -2.961 & -2.613 & $\mathrm{I}(1)$ & Stationary \\
VAT & $4.358^{* * *}$ & 3.750 & 3.000 & -2.630 & $\mathrm{I}(1)$ & Stationary \\
CORPT & $3.865^{* * *}$ & -3.655 & -2.961 & -2.613 & $\mathrm{I}(1)$ & Stationary \\
CUSEXC & 3.114 & 3.750 & 3.000 & -2.630 & $\mathrm{I}(1)$ & Stationary \\
\hline
\end{tabular}

$(*),(* *)$ and $(* * *)$ means stationary at $1 \% .5 \%$ and $10 \%$ respectively

Source: Author's computation (2018)

Table 1 showed that ADF stat of all variables are greater that all the critical vales $(1 \%, 5 \%$ and $10 \%$ critical values which made all variables stationary at $5 \%$ level of significant, that is all the variables are co-integrated). All the variables are stationary at first level which exhibited that there is a long run relationship between taxation and investment in Nigeria.

Table 2. The Effect of Tax Income on Investment in Nigeria

\begin{tabular}{|l|l|l|l|l|l|ll|}
\hline $\begin{array}{c}\text { Dependent } \\
\text { variables }\end{array}$ & $\begin{array}{c}\text { Independent } \\
\text { variables }\end{array}$ & Coefficient & $\begin{array}{l}\text { Standard } \\
\text { error }\end{array}$ & $\mathrm{T}$ & $\mathrm{P}>/ \mathrm{T} /$ & \multicolumn{2}{|c|}{ (95\% conf. Interval) } \\
\hline \multirow{4}{*}{ LOGINV } & LOGPPT & 0.1636448 & 0.0487803 & 3.35 & 0.004 & 0.0596721 & 0.2676174 \\
\cline { 2 - 8 } & LOGVAT & 0.2160115 & 0.1299643 & 2.66 & 0.017 & -0.0610009 & 0.4930238 \\
\cline { 2 - 8 } & LOGCORPT & -0.0704139 & 0.0396542 & -3.85 & 0.014 & -0.0141071 & 0.1549349 \\
\cline { 2 - 8 } & LOGCUSEXC & -0.2452478 & 0.1540096 & -1.59 & 0.132 & -0.5735115 & 0.0830159 \\
\cline { 2 - 8 } & CONSTANT & 9.433373 & 0.564367 & 16.71 & 0.000 & 8.230453 & 10.63629 \\
\hline \multirow{2}{*}{$\begin{array}{l}\text { R-squared } \\
=0.7095\end{array}$} & $\begin{array}{l}\text { Adj R-squared } \\
=0.6854\end{array}$ & $\begin{array}{l}\text { Prob }>\mathrm{F}= \\
0.0000\end{array}$ & $\begin{array}{l}\text { Root MSE } \\
0.14965\end{array}$ & $=$ & $\mathrm{F}(4$, & $15)=37.68$ & \\
\hline
\end{tabular}

Source: Author's computation (2018) 

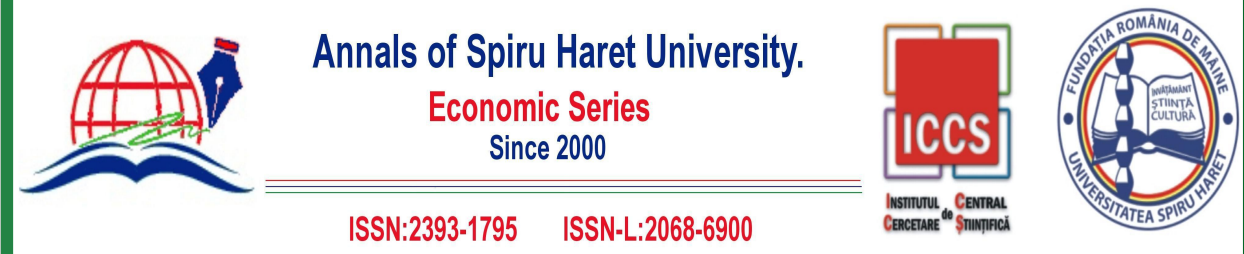

Issue 4/2019

Table 2 shows the effect of taxation on investment in Nigeria. $1 \%$ increase in the Petroleum profit tax (PPT) increases investment (INV) by $0.16 \%$. This suggests a positive significant effect of PPT on INV. The outcome is significant $(\beta=0.1636448$, $\mathrm{t}=3.35, \mathrm{P}>|\mathrm{t}|=0.004) .1 \%$ increase in Value added tax (VAT) increases GDP by $0.2 \%$. This means that VAT imparted INV positively and significantly $(\beta=0.2160115$, $\mathrm{t}=2.66, \mathrm{P}>|\mathrm{t}|=0.017)$. That is if VAT increases, INV increases. Contrarily, $1 \%$ increase in the corporate income tax (CORPT) reduces INV by $0.7 \%$. This suggests a negative significant effect $(\beta=-0.0704139, \mathrm{t}=3.85, \mathrm{P}>|\mathrm{t}|=0.014)$ of CORPT on INV. More so, $1 \%$ increase in Custom and excise duty (CUSEXC) reduces INV by $0.24 \%$. This also reveals a negative insignificant effect of CUSEXC on INV ( $\beta=$ $-0.2452478, \mathrm{t}=-1.59, \mathrm{P}>|\mathrm{t}|=0.132$ ). This is suggesting that if CUSEXC in Nigeria increases, INV also reduces.

Given coefficient of determination $\left(\mathrm{R}^{2}\right)$ as $0.7095(70 \%)$ with the high value of adjusted $\mathrm{R}^{2}$ as $68.5 \%$, it shows that the independent variables explained $69 \%$ of the observed variation in investment in Nigeria, the remaining $31 \%$ are for error terms. The $\mathrm{F}$ and probability statistics also confirmed the significance of this model. This hypothesis is to test whether or not there is significant effect of taxation on investment in Nigeria. From the decision rule above, because the p-value equals 0.0000 , which is less than 0.05 , therefore the null hypothesis is rejected while the alternative hypothesis is upheld. Therefore, taxation has significant effect on investment in Nigeria.

Table 3. Selection-Order Criteria

\begin{tabular}{llll|lllll}
\hline & & & & & & & & \\
\multicolumn{1}{c}{ Lag } & LL & LR & Df & p & FPE & AIC & HQIC & SBIC \\
\hline 0 & -2728.9 & & & & $1.6 \mathrm{e}+53$ & 136.695 & 136.771 & 136.906 \\
1 & -2569.4 & 319 & 25 & 0.000 & $1.9 \mathrm{e}^{+}+50$ & 129.97 & 130.428 & 131.237 \\
2 & -2492.97 & 152.86 & 25 & 0.000 & $1.6 \mathrm{e}+49$ & 127.398 & 128.238 & 129.721 \\
3 & -2343.36 & 299.22 & 25 & 0.000 & $3.7 \mathrm{e}+46$ & 121.168 & 128.238 & 124.546 \\
4 & -2058.88 & $568.96^{*}$ & 25 & 0.000 & $1.2 \mathrm{e}^{+41 *}$ & $108.194^{*}$ & $109.797^{*}$ & $112.627^{*}$ \\
\hline
\end{tabular}

Endogenous: INV, PPT, VAT, CORPT, CUSEXC

Exogenous:_cons 


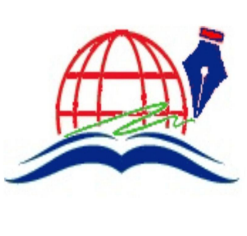

Annals of Spiru Haret University.

Economic Series

Since 2000

ISSN:2393-1795 ISSN-L:2068-6900
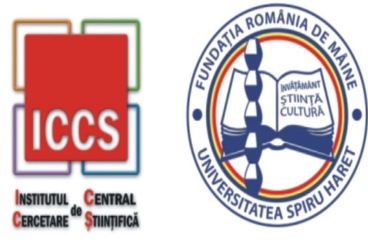

\section{Issue 4/2019}

The Hannan-Quinn information criterion (HQIC) method, Schwarz Bayesian information criterion (SBIC) method, and sequential likelihood-ratio (LR) test all chose four lags, as indicated by the "*" in the output. Both the SBIC and the HQIC estimators suggested that four co-integrating equations existed among the variables. Having determined that there is a co-integrating equation among the GDP, PPT, VAT, CORPT and CUSEXC series, the parameters of a bivariate co-integrating VECM for these four series by using Vector error-correction model were estimated in Table 3. Lags four was used for this bivariate model because HQIC, SBIC and LR test selected four lags, as indicated by the "*" in the output.

Table 4: Vector Autoregression

\begin{tabular}{|c|c|c|c|c|c|}
\hline Equation & Parms & RMSE & $\mathrm{R} \mathrm{sq}$ & chi2 & $\mathrm{P}>$ chi2 \\
\hline INV & 21 & 7321.95 & 0.9978 & 18026.65 & 0.0000 \\
\hline PPT & 21 & 44223.3 & 0.9994 & 72559.67 & 0.0000 \\
\hline VAT & 21 & 34730.1 & 0.9998 & 191407.4 & 0.0000 \\
\hline CORPT & 21 & 44796 & 0.9997 & 159157.7 & 0.0000 \\
\hline CUSEXC & 21 & 21720 & 0.9998 & 216422.1 & 0.0000 \\
\hline $\begin{array}{l}\text { Log likelihood } \\
=-2058.876\end{array}$ & $\begin{array}{l}\text { Det (Sigma_ml) } \\
=3.51 \mathrm{e}+38\end{array}$ & $\begin{array}{ll}\mathrm{AIC} & = \\
108.1938\end{array}$ & $\begin{array}{l}\text { HQIC } \\
109.7967\end{array}$ & SBIC & $=112.6271$ \\
\hline
\end{tabular}

Source: Author's computation (2018)

In order to confirm the output result of selection-order criteria in selecting the appropriate lag, vector autoregression was also tested. Lags four was also chosen for this model because the Hannan-Quinn information criterion (HQIC) method, Schwarz Bayesian information criterion (SBIC) method, and sequential likelihoodratio (LR) test confirmed four lags as indicated by in the Table 4.

Table 5. Vector Error-Correction Model

\begin{tabular}{|lllllc|}
\hline Equation & Parms & RMSE & R sq & chi2 & P $>$ chi2 \\
D_INV & 7 & 0.049329 & 0.9306 & 147.4676 & 0.0000 \\
D_PPT & 7 & 0.58922 & 0.3032 & 4.787472 & 0.6859 \\
D_VAT & 7 & 0.572748 & 0.4574 & 9.27106 & 0.2338 \\
\hline D_CORPT & 7 & 0.631593 & 0.3433 & 5.750349 & 0.5692 \\
\hline D_CUSEXC & 7 & 0.993357 & 0.3895 & 7.016821 & 0.4271 \\
\hline Log likelihood & Det (Sigma_ml) & AIC & HQIC & SBIC & $=3.140841$ \\
$=28.09468$ & $=3.03 \mathrm{e}-08$ & $=1.211702$ & $=1.477705$ & & \\
\hline
\end{tabular}

66 


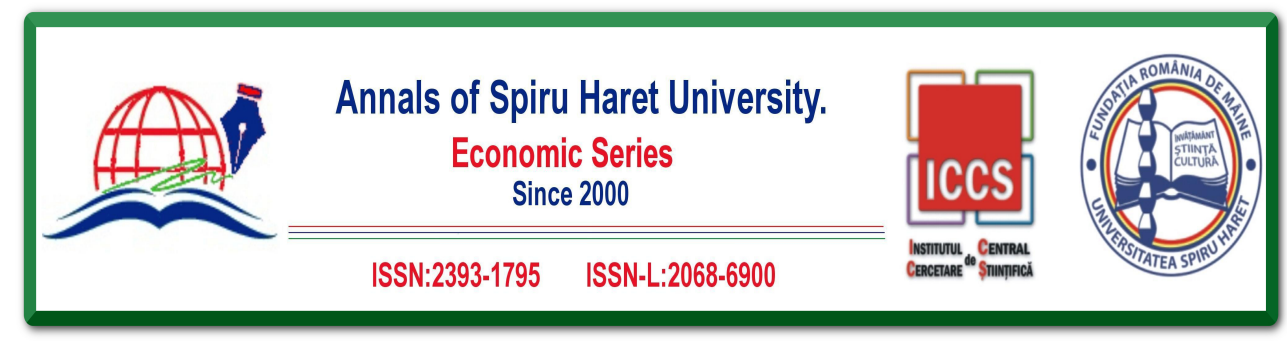

Issue 4/2019

\begin{tabular}{|c|c|c|c|c|c|}
\hline Variable & Coefficient & Std Error & $\mathrm{Z}$ & $\mathrm{P}>|\mathrm{z}|$ & [95\% Conf. Interval] \\
\hline D_INV_ce1 L1. & 0.0010729 & 0.0090284 & 0.12 & 0.905 & $\begin{array}{ll}-0.0166223 & 0.0187682\end{array}$ \\
\hline INV LD. & 0.1513765 & 0.1679185 & 0.90 & 0.367 & $\begin{array}{ll}-0.1777378 & 0.4804908\end{array}$ \\
\hline PPT LD. & 0.0072754 & 0.0053063 & 1.37 & 0.170 & $-0.0031246 \quad 0.0176755$ \\
\hline VAT LD. & 0.1251278 & 0.0765562 & 1.63 & 0.102 & $\begin{array}{ll}-0.0249197 & 0.2751753\end{array}$ \\
\hline CIT LD & 0.0116651 & 0.0144937 & 0.80 & 0.421 & $-0.0167421 \quad 0.0400723$ \\
\hline CUSEXC LD & -0.2071355 & 0.0989234 & -2.09 & 0.036 & $-0.4010218 \quad-0.0132492$ \\
\hline - CONS & 5651.763 & 2350.602 & 2.40 & 0.016 & 1044.667 \\
\hline D_PPT_ce1 L1. & -0.8731796 & 0.331642 & -2.63 & 0.008 & $-1.523186 \quad-0.2231732$ \\
\hline INV LD. & -1.019751 & 6.168216 & -0.17 & 0.869 & -13.10923 \\
\hline PPT LD. & -0.5139666 & 0.1949168 & -2.64 & 0.008 & $\begin{array}{cc}-0.8959966 & -0.1319367\end{array}$ \\
\hline VAT LD. & -4.912724 & 2.81217 & -1.75 & 0.081 & 0.5990282 \\
\hline CIT LD & -0.2810865 & 0.5324035 & -0.53 & 0.598 & 0.7624053 \\
\hline CUSEXC LD & 5.633751 & 3.633791 & 1.55 & 0.121 & -1.488349 \\
\hline - CONS & 77215.21 & 86345.57 & 0.89 & 0.371 & -92019.01 \\
\hline D_VAT_ce1 L1. & -2.184293 & 386 & -5.64 & 0.000 & -2.943975 \\
\hline INV LD. & -9.095154 & 7.208979 & -1.26 & 0.000 & -23.22449 \\
\hline PPT LD. & 0.3510334 & 0.2278051 & 1.54 & 0.000 & $\begin{array}{ll}-0.0954564 & 0.7975232\end{array}$ \\
\hline VAT LD. & -20.72566 & 3.286667 & -6.31 & 0.000 & -27.16741 \\
\hline CIT LD & 1.009667 & 0.622236 & 4.24 & 0.000 & -0.2098933 \\
\hline CUSEXC LD & 23.26025 & 4.246921 & 5.48 & 0.000 & 14.93644 \\
\hline - CONS & -5912.86 & 100914.7 & 8.97 & 0.000 & 191876.2 \\
\hline D_CIT_ce1 L1. & -2.641875 & 0.4523768 & -5.84 & 0.000 & -3.528517 \\
\hline INV LD. & -9.952393 & 8.413765 & -2.37 & 0.010 & -26.44307 \\
\hline PPT LD. & 0.4555922 & 0.2658766 & 3.76 & 0.004 & $\begin{array}{ll}-0.0655163 & 0.9767008\end{array}$ \\
\hline VAT LD. & -25.34064 & 3.835945 & -6.61 & 0.000 & -32.85895 \\
\hline CIT LD & 1.141143 & 0.7262259 & 5.39 & 0.000 & -0.2822337 \\
\hline CUSEXC LD & 28.6292 & 4.956679 & 5.78 & 0.000 & 18.91429 \\
\hline - CONS & -1958941 & 117779.8 & 8.35 & 0.000 & -250433.6 \\
\hline
\end{tabular}




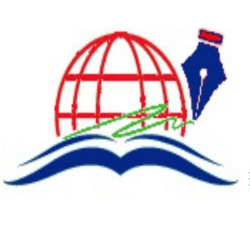

Annals of Spiru Haret University.

Economic Series

Since 2000

ISSN:2393-1795 ISSN-L:2068-6900
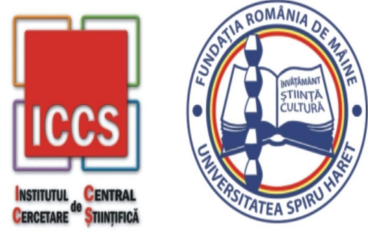

Issue 4/2019

\begin{tabular}{|l|l|l|l|l|lr|}
\hline D_CUSEXC_ce1 L1. & -1.413916 & 0.265703 & -5.32 & 0.000 & -1.934685 & -0.893148 \\
\hline INV LD. & -6.051887 & 4.941815 & -1.22 & 0.221 & -15.73767 & 3.633892 \\
\hline PPT LD. & 0.2578157 & 0.1561623 & 1.65 & 0.000 & -0.0482568 & 0.5638881 \\
\hline VAT LD. & -13.54734 & 2.253038 & -6.01 & 0.000 & -17.96321 & -9.131468 \\
\hline CIT LD & 0.6609143 & 0.4265479 & 4.56 & 0.000 & -0.1751042 & 1.496933 \\
\hline CUSEXC LD & 15.23959 & 2.911299 & 5.23 & 0.000 & 9.533551 & 20.94563 \\
\hline - CONS & -1943.877 & 69177.83 & 9.78 & 0.000 & 137529.9 & 133642.2 \\
\hline
\end{tabular}

\begin{tabular}{|l|l|l|l|}
\hline Equation_ce1 & - & Parms 4 & chi2 \\
464.8528 & P $>$ chi2 \\
\cline { 1 - 1 } Identification: beta is exactly identified & & 0.0000 \\
\hline
\end{tabular}

Source: Authors' Computation (2018)

Table 6. Johansen Normalization Restriction Imposed

\begin{tabular}{|c|c|c|c|c|c|c|}
\hline Beta & Coefficient & Std Error & $\mathrm{Z}$ & $\mathrm{P}>|\mathrm{z}|$ & \multicolumn{2}{|c|}{ [95\% Conf. Interval] } \\
\hline cel INV & 1 & & & & & \\
\hline$\overline{\mathrm{PPT}}$ & 0.3394484 & 0.0383473 & 8.85 & 0.000 & 0.2642891 & 0.4146077 \\
\hline VAT & -0.0166819 & 0.0633606 & -4.62 & 0.003 & -0.1408664 & 0.1075025 \\
\hline CORPT & -0.1130951 & 0.0201892 & -5.60 & 0.002 & -1.521709 & -1.123658 \\
\hline CUSEXC & -1.322683 & 0.1015455 & -13.03 & 0.000 & -0.1526652 & -0.0735249 \\
\hline -CONS & -161252.1 & & & & & \\
\hline
\end{tabular}

Source: Author's computation (2018)

Table 5 and Table 6 contain information about the sample, the fit of each equation, and overall model fit statistics. The first estimation table contains the estimates of the short-run parameters, along with their standard errors, $\mathrm{z}$ statistics, and confidence intervals. The three coefficients on L. cel are the parameters in the adjustment matrix - for this model. The second estimation table contains the estimated parameters of the co-integrating vector for this model, along with their standard errors, $\mathrm{z}$ statistics, and confidence intervals. According to Johansen normalization restriction imposed table, one per cent increase in PPT increases INV by $0.3 \%$ in the long run, this shows that there is positive relationship between PPT 

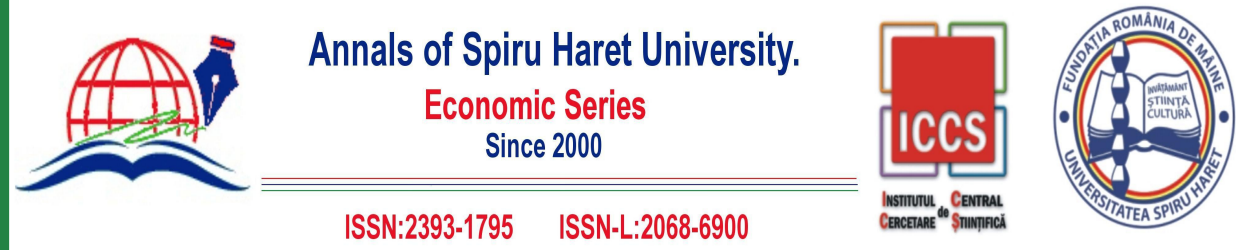

Issue 4/2019

and INV. Contrarily, one per cent increase in VAT, reduces INV by $0.001 \%$ in the long run, this shows that there is a negative significant relationship between VAT and INV in the long run. Also, one per cent increase in CORPT, reduces INV by $0.011 \%$ in the long run, this also shows that there is a negative significant relationship between CORPT and INV in the long run. More so, one per cent increase in CUSEXC reduces INV by $1.3 \%$ in the long run, this shows that there is a negative significant relationship between CUSEXC and INV in the long run. Coefficient is statistically significant confirmed by $\mathrm{P}>|\mathrm{z}|$ which is 0.000 . Overall, the output indicates that the model fits well. The coefficient on INV in the co-integrating equation is statistically significant, as are the adjustment parameters.

Table 7. Johansen Tests for Co-integration

\begin{tabular}{llllllll}
\hline Rank & $\begin{array}{l}\text { Eigen } \\
\text { Value }\end{array}$ & Parm & LL & $\begin{array}{l}\text { Trace } \\
\text { statistic }\end{array}$ & $\begin{array}{l}5 \% \\
\text { critical } \\
\text { value }\end{array}$ & $\begin{array}{l}1 \% \\
\text { critical }\end{array}$ & $\begin{array}{l}\text { Eigen } \\
\text { Value }\end{array}$ \\
\hline 0 & - & 80 & -2366.2345 & 614.7179 & 68.52 & 76.07 & - \\
1 & 0.99939 & 89 & -2218.3076 & 318.8640 & 47.21 & 54.46 & 0.99939 \\
2 & 0.99515 & 96 & -2111.7123 & 105.6735 & 29.68 & 35.65 & 0.99515 \\
3 & 0.88719 & 101 & -2068.0705 & 18.3899 & 15.41 & 20.04 & 0.88719 \\
4 & 0.36555 & 104 & -2058.9706 & $0.1901 * 1 * 5$ & 3.76 & 6.65 & 0.36555 \\
5 & 0.00474 & 105 & -2058.8756 & & & & 0.00474 \\
\hline
\end{tabular}

Source: Author's computation (2018)

Table 7 produced information about the sample, the trend specification, and the number of lags included in the model. The main table contains a separate row for each possible value of $r$, the number of co-integrating equations. When $r=3$, all three variables in the model are stationary. In this study, because the trace statistic at $r=0$ of 614.7179 exceeds its critical value of 68.52 , the null hypothesis of no cointegrating equations are rejected. Similarly, because the trace statistic at $r=1$ of 318.8640 exceeds its critical value of 47.21 , the null hypothesis that there is one or fewer co-integrating equations is also rejected. In the same vein, because the trace statistic at $r=2$ of 105.6735 exceeds its critical value of 29.68, the null hypothesis that there is two or fewer co-integrating equations is also rejected. The trace statistic at $r=3$ of 18.3899 exceeds its critical value of 15.41 , the null hypothesis that there is 


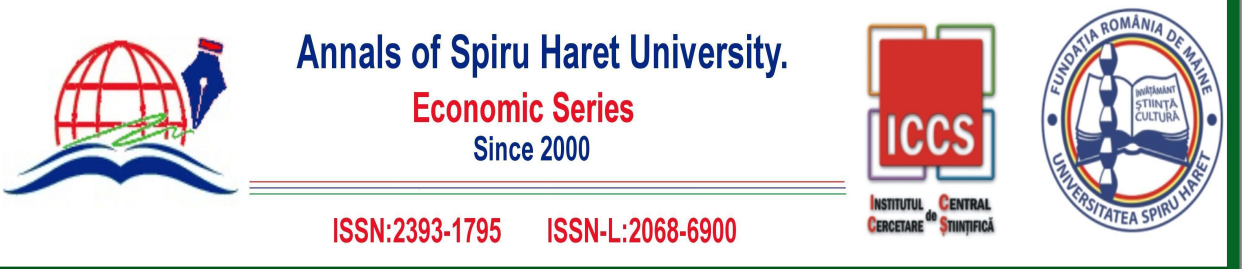

\section{Issue 4/2019}

three or fewer co-integrating equations is also rejected. In contrast, because the trace statistic at $\mathrm{r}=4$ of $0.1901 * 1 * 5$ is less than its critical value of 3.76 , the null hypothesis that there are four or fewer co-integrating equations cannot be rejected. Because Johansen's method for estimating $r$ is to accept as $r^{\mathrm{n}}$ the first $r$ for which the null hypothesis is not rejected, $r=4$ is accepted as the estimate of the number of cointegrating equations between these five variables. The "*" by the trace statistic at $\mathrm{r}=$ 4 indicates the value of $r$ selected by Johansen's multiple-trace test procedure. The eigenvalue shown in the last line of output computes the trace statistic in the preceding line.

Table 8. Granger Causality Wald Tests - Causality between Investment and Taxation

\begin{tabular}{|ll|lll|l|}
\hline Equation & Excluded & chi2 & Df & Prob $>$ chi2 & \\
\hline INV & PPT & 60.192 & 4 & 0.000 & Decision \\
INV & VAT & 56.844 & 4 & 0.000 & VAT granger-cause INV \\
INV & CORPT & 64.268 & 4 & 0.000 & CORPT granger-cause INV \\
INV & CUSEXC & 77.263 & 4 & 0.000 & CUSEXC granger-cause INV \\
\hline PPT & ALL & 161.17 & 16 & 0.000 & ALL jointly granger-cause INV \\
PPT & VAT & 67.854 & 4 & 0.037 & INV granger-cause PPT \\
PPT & CORPT & 52.195 & 4 & 0.000 & VAT granger-cause PPT \\
PPT & CUSEXC & 55.937 & 4 & 0.000 & CORPT granger-cause PPT \\
PPT & ALL & 7982.8 & 10 & 0.000 & CUSEXC granger-cause PPT \\
\hline VAT & INV & 30.868 & 4 & 0.000 & ALL jointly granger-cause PPT \\
VAT & PPT & 445.28 & 4 & 0.000 & PPT granger-cause VAT \\
VAT & CORPT & 329.14 & 4 & 0.000 & CORPT granger-cause VAT \\
VAT & CUSEXC & 938.23 & 4 & 0.000 & CUSEXC granger-cause VAT \\
VAT & ALL & 21782 & 10 & 0.000 & ALL jointly granger-cause VAT \\
\hline CORPT & INV & 47.92 & 4 & 0.000 & INV granger-cause CORPT \\
CORPT & PPT & 173.55 & 4 & 0.000 & PPT granger-cause CORPT \\
CORPT & VAT & 1926.5 & 4 & 0.000 & VAT granger-cause CORPT \\
CORPT & CUSEXC & 875.68 & 4 & 0.000 & CUSEXC granger-cause CORPT \\
\hline
\end{tabular}




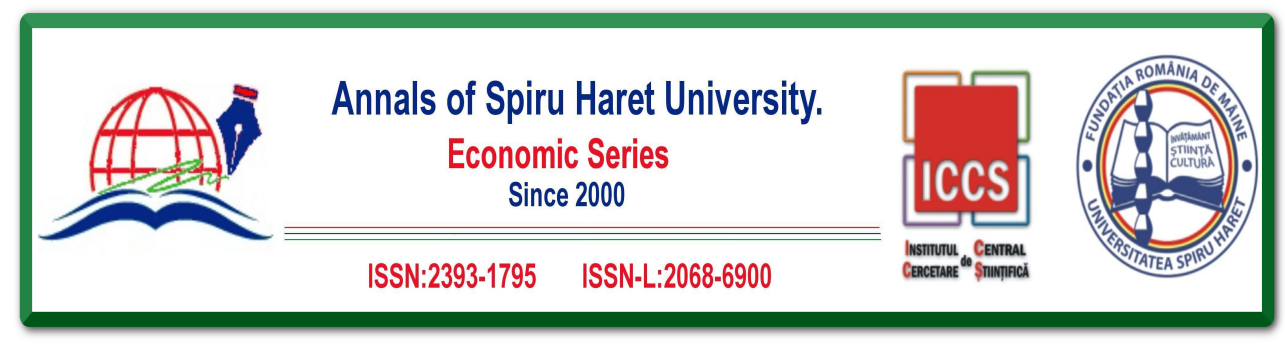

Issue 4/2019

\begin{tabular}{|ll|lll|l|} 
CORPT & ALL & 55331 & 16 & 0.000 & ALL jointly granger-cause CORPT \\
\hline CUSEXC & INV & 42.791 & 4 & 0.000 & INV granger-cause CUSEXC \\
CUSEXC & PPT & 500.07 & 4 & 0.000 & PPT granger-cause CUSEXC \\
CUSEXC & VAT & 3396.5 & 4 & 0.000 & VAT granger-cause CUSEXC \\
CUSEXC & CORPT & 277.42 & 4 & 0.000 & CORPT does not granger-cause CUSEXC \\
CUSEXC & ALL & 62947 & 16 & 0.000 & ALL jointly granger-cause CUSEXC \\
\hline
\end{tabular}

Source: Authors' Computation (2018)

Consider the results of the five tests for the first equation in the Table 8. The first is a Wald test that the coefficients on the four lags of PPT that appear in the equation for INV are jointly zero. The null hypothesis that PPT does not Granger-cause INV cannot be accepted because Prob $>\mathrm{chi}^{2}$ is 0.000 , therefore PPT granger-cause INV. Also, the null hypothesis that the coefficients on the four lags of VAT in the equation for INV are jointly zero cannot be accepted because Prob $>$ chi2 is 0.000 . Therefore, the hypothesis that VAT does not Granger-cause INV cannot be accepted, therefore VAT granger-cause INV. The null hypothesis that CORPT does not Granger-cause INV cannot be accepted because Prob $>\mathrm{chi}^{2}$ is 0.000 , therefore CORPT grangercause INV. More so, the null hypothesis that the coefficients on the four lags of CUSEXC in the equation for INV are jointly zero cannot be accepted because Prob > chi2 is 0.000 , therefore CUSEXC granger-cause INV. The fifth null hypothesis is that the coefficients on the four lags of all the other endogenous variables are jointly zero. This null hypothesis cannot be accepted because Prob $>$ chi2 is 0.000 that is that PPT, VAT, CORPT and CUSEXC, jointly, Granger-cause INV. Therefore the null hypothesis is rejected, alternative hypothesis is accepted that is there is causality between taxation and investment.

Table 9 showed the results of the causality analysis among petroleum profit tax (PPT), value added tax (VAT), corporate income tax (CORPT), custom and excise duties (CUSEXC) and investment (INV). The results showed that causality ran from petroleum profit tax (PPT) to investment (INV) and vice versa. This result indicated that bidirectional causality existed between the two variables in Nigeria. Furthermore, the findings revealed that the causality ran from value added tax (VAT) to INV, while VAT also granger cause INV. This result also indicated that bidirectional causality existed between VAT and INV. Also, corporate income tax (CORPT) with the Chi- 


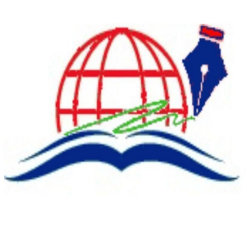

Annals of Spiru Haret University.

Economic Series

Since 2000
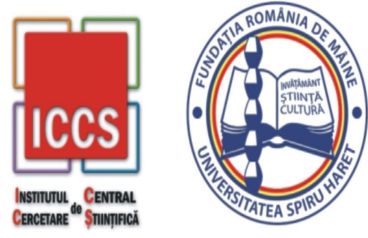

\section{Issue 4/2019}

square statistic (64.268) and the probability value (0.000), being statistically significant, granger-caused INV. In the same vein, INV also granger-caused CORPT. This indicated that bidirectional causality existed between CORPT and INV. More so, it was revealed that custom and excise duties (CUSEXC) with the Chi-square statistic 77.263 and the probability value 0.000 , being statistically significant, granger-caused INV. INV also granger-caused CUSEXC. These results showed that there was a feedback effect from taxation to investment and from investment to taxation. Therefore, all the component of taxation showed causal relationship with investment.

Table 9. Direction of Causality between Investment and Taxation

\begin{tabular}{|c|c|c|c|c|c|c|}
\hline Equation & Excluded & chi2 & Df & $\begin{array}{l}\text { Prob }> \\
\text { chi2 }\end{array}$ & Decision & $\begin{array}{l}\text { Direction of } \\
\text { Causality }\end{array}$ \\
\hline INV & PPT & 60.192 & 4 & 0.000 & PPT granger-cause INV & PPT $\rightarrow$ INV \\
\hline PPT & INV & 7.8545 & 4 & 0.097 & INV granger-cause PPT & INV $\rightarrow$ PPT \\
\hline INV & VAT & 56.844 & 4 & 0.000 & VAT granger-cause INV & $\mathrm{VAT} \rightarrow \mathrm{INV}$ \\
\hline VAT & INV & 30.868 & 4 & 0.000 & INV granger-cause VAT & INV $\rightarrow$ VAT \\
\hline INV & CORPT & 64.268 & 4 & 0.000 & CORPT granger-cause INV & CORPT $\rightarrow$ INV \\
\hline CORPT & INV & 47.92 & 4 & 0.000 & INV granger-cause CORPT & INV $\rightarrow$ CORPT \\
\hline INV & CUSEXC & 77.263 & 4 & 0.000 & $\begin{array}{l}\text { CUSEXC granger-cause } \\
\text { INV }\end{array}$ & CUSEXC $\rightarrow$ INV \\
\hline CORPT & INV & 47.92 & 4 & 0.000 & INV granger-cause CORPT & INV $\rightarrow$ CUSEXC \\
\hline
\end{tabular}

Source: Author's computation (2018)

\section{Conclusion}

This study examined the effect of taxation on investment in Nigeria from 1970 to 2018. Secondary data were used in this study. The relevant data for the study were obtained from Central Bank of Nigeria (CBN) Statistical Bulletins and Federal Inland Revenue Services Bulletin from 1970 to 2018. Regression analysis technique was used to measure the effects of independent variables on dependent variable while Units root test, Johansen co-integration, Vector Error-Correction Model, and Granger 


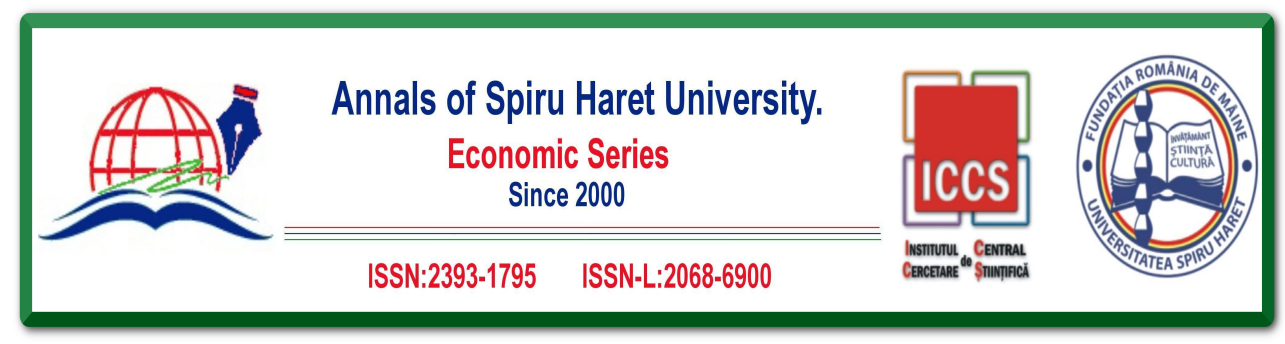

Issue 4/2019

causality tests were employed to determine the long run relationship and causality links among the variables. Results showed that PPT has positive significant impact on INV both in the short run and in the long run $(\beta=0.1636448 ; \mathrm{t}=3.35 ; \mathrm{P}>|\mathrm{t}|=$ $0.000)$ and $(\beta=0.1269068 ; \mathrm{z}=-5.99, \mathrm{P}>|\mathrm{z}|=0.000)$. Also, PPT granger causes INV. The study also reviewed that Value added tax has positive significant impact on INV in the short run $(\beta=0.2160115 ; \mathrm{t}=2.66, \mathrm{P}>|\mathrm{t}|=0.000)$ but negative significant impact in the long run $(\beta=-0.0166819 ; \mathrm{z}=-4.62, \mathrm{P}>|\mathrm{z}|=0.000)$. VAT grangers cause INV. Company income tax, and Custom and Excise duties impacted INV negatively both in the short run $(\beta=-0.0704139 ;-0.2452478, \mathrm{t}=-3.85,-1.59, \mathrm{P}>|\mathrm{t}|=0.000)$ and in the long run $(\beta=-0.1130951 ;-1.322683, \mathrm{z}=-5.60 ;-13.03 ; \mathrm{P}>|\mathrm{z}|=0.000)$ respectively. CORPT granger causes INV and CUSEXC also granger causes INV.

It is concluded that all components of taxes had positive significant impact on investment in Nigeria except corporate income tax. Corporate income tax had negative significant impact on investment both in the short run and in the long run. Petroleum profit tax had positive significant impact on investment both in the short run and in the long run in Nigeria. Taxation had long run effect on investment in Nigeria. It is recommended that tax incentives should be given to corporate organisations, this will create enabling environment for investment to thrive so as to complement the efforts of the government in provisioning the employment opportunity in the country.

\section{References}

[1] Adegbite, T.A., \& Usman, O.A. (2017). "Empirical Analysis of the Effect of Taxation on Investment in Nigeria." International Journal in Commerce, IT \& Social Sciences, 4(8): 111.

[2] Buttner, T., Overesch, M., Schreiber, U., \& Wamser, G. (2006). "The Impact of ThinCapitalization Rules on Multinationals' Financing and Investment Decisions," Discussion paper, ZEW No. 06-068.

[3] Chigbu, E.E., Eze, A.L., \& Appah, E. (2012). "An Empirical Study on the Causality between Economic Growth and Taxation in Nigeria." Current Research Journal of Economic Theory.

[4] Edame, G.E. and Okoi, W.W. (2014). "The Impact of Taxation on Investment and Economic Development in Nigeria." Academic Journal of Interdisciplinary Studies, 3(4), 209-218. 

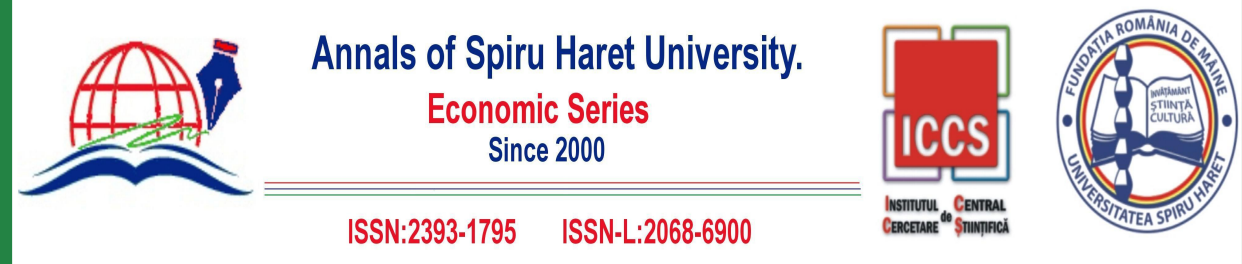

\section{Issue 4/2019}

[5] Harberger, C. (1962). "The incidence of the corporation income tax." The Journal of Political Economy, 70 (3), 215-240.

[6] Iyoha, M.A. Applied econometrics. Revised edition. Benin City, Mindex Publishing, 2006.

[7] Jhingan, M.L. Macroeconomics Theory and Policies, New Delhi, Vanek Publishing Company Ltd, 1976.

[8] Mihai, I.M., \& Dan, C.D. (2011). "Taxes and Economic Growth in Romania: A VAR Approach." Annales Universitatis Apulensis Series Oconomica, 13(1), 94-105.

[9] Mika, M., Andrew, H.M., \& Shiv, K.T. (2012). "Study of Tax System Impact on the Growth of Small and Medium Enterprises (SMES); with Reference to Shinyanga Municipality, Tanzania." International Journal of Management and Business Studies, 2 (3): 99-105.

[10] Muhammed, M.A., \& Jumbo, K.L. (2012). "Tax Reforms and Revenue Productivity in Pakistan." Asian Journal of Social Scences, 5(2): 13-24.

[11] Nwokoye, G.A., \& Rolle, R.A. (2015). "Tax Reforms and Investment in Nigeria: An Empirical Examination." International Journal of Development and Management Review (INJODEMAR); 10(2): 39-51.

[12] Rodrigo, L.A. (2004). "Tax Reforms and Private Investment in Chile." Journal of Management Sciences, 4(8).

[13] Tosun, M.S., \& Abizadeh, S. (2005). "Economic growth and tax components: An Analysis of Tax changes in OECD.” Applied Economics Journal, 3(7): 2251-2263. 